\title{
Including road transport in the EU ETS (European Emissions Trading System): A model-based analysis of the German electricity and transport sector
}

\author{
Heidi Heinrichs ${ }^{\mathrm{a}, *}$, Patrick Jochem ${ }^{\mathrm{b}}$, Wolf Fichtner ${ }^{\mathrm{b}}$ \\ a Institute of Energy and Climate Research (IEK), System Analysis and Technology Evaluation (IEK-STE), Forschungszentrum Jülich, Wilhelm-Johnen-Straße, \\ 52425 Jülich, Germany \\ ${ }^{\mathrm{b}}$ Institute for Industrial Production (IIP), Chair of Energy Economics, Karlsruhe Institute of Technology (KIT), Hertzstraße 16, Building 06.33, \\ 76187 Karlsruhe, Germany
}

Keywords:

$\mathrm{CO}_{2}$ emissions trading

Electricity sector

Road transport

\begin{abstract}
A B S T R A C T
The EU ETS (European Emissions Trading System) is being enlarged stepwise to cover an increasing amount of overall European $\mathrm{CO}_{2}$ emissions. However, one of the largest and still growing $\mathrm{CO}_{2}$ emitting sector, the transport sector, and particularly road transport, has not yet been included in the EU ETS. Against this background, the question arises whether integrating the road transport sector in the EU ETS represents a cost efficient $\mathrm{CO}_{2}$ reduction strategy. For this reason, the consequences of this integration are analysed with a focus on Germany. To do so we utilise a model based approach. In order to account for both sectors simultaneously, we couple an electricity system model, PERSEUS EU (Package for Emission Reduction Strategies in Energy Use and Supply in Europe), with a road transport model, COMIT $\left(\mathrm{CO}_{2}\right.$ emission Mitigation in the Transport sector). The time horizon we consider ranges from 2010 to 2030. In our analysis, we differentiate our scenarios according to commodity prices, share of renewable energies in electricity generation and share of electric vehicles. The results show that the enlargement of the EU ETS to include road transport leads to a reduction of overall $\mathrm{CO}_{2}$ emissions, but equally reduces the mitigation efforts in the road transport sector. Simultaneously, the German electricity sector is mainly influenced according to the certificate demand or supply of the road transport sector.
\end{abstract}

\section{Introduction}

In order to reach the Kyoto targets, the EU ETS (European Emission Trading System) was established in 2005 according to EU directive 2003/87/EC and already covers 30 countries (the $27 \mathrm{EU}$ Member States in 2010 plus Norway, Iceland, and Liechtenstein) [1]. Until now it has been structured into four periods up to 2028 with varying restrictions. Whereas so far national caps have been allo cated, in the third phase of the EU ETS (2013-2020) only one single Europe wide cap is applied. Furthermore, the European Union has standardised the installations affected by the EU ETS as well as the allocation and auctioning of $\mathrm{CO}_{2}$ allowances. In this way, $\mathrm{CO}_{2}$ emissions are to be reduced where it is most cost efficient.

Two major $\mathrm{CO}_{2}$ emitting sectors are excluded from the EU ETS. These are the residential sector with a share of $9.9 \%$ of overall $\mathrm{CO}_{2}$

\footnotetext{
* Corresponding author. Tel.: +49 246161 9166; fax: +49 2461612540 .

E-mail addresses: h.heinrichs@fz-juelich.de (H. Heinrichs), jochem@kit.edu (P. Jochem), wolf.fichtner@kit.edu (W. Fichtner).
}

emissions in the European Union (EU27) in 2007 and transport, which is the only sector without emission reductions so far. In 2007, $\mathrm{CO}_{2}$ emissions from transport increased by 25\% compared to 1990 and had a share of $23.1 \%$ in the EU27 $\mathrm{CO}_{2}$ emissions [2]. More than $71 \%$ of these emissions in 2007 originated from road transport [3].

From an economic point of view, these framework conditions are inefficient: some sectors in the EU ETS struggle to reduce their emissions, while others are not affected by the limitations (i.e. transport sector). The latter increases the pressure on those already "suffering" from the EU ETS. These inefficiencies are most apparent in the transport sector, as its emissions are still growing and will continue to increase on a European scale and are going to double on the global scale up to 2050 [4]. This development strongly conflicts with the long term $\mathrm{CO}_{2}$ emission targets of industrialised nations, such as Germany, which is striving to reduce $\mathrm{CO}_{2}$ emissions by $30-$ $40 \%$ by 2030 compared to 1990 and by about $80 \%$ by $2050[5,6]$. Another policy instrument in this issue is the European Directive $443 / 2009$, which forces vehicle manufacturers to meet the vehicle specific $\mathrm{CO}_{2}$ emissions of $95 \mathrm{~g}$ per $\mathrm{km}$ by 2020 for new passenger 


\section{Abbreviations} \\ BEV battery electric vehicle \\ CDM Clean Development Mechanisms \\ $\mathrm{CO}_{2} \quad$ carbon dioxide \\ COMIT $\mathbf{C O}_{2}$ emission Mitigation in the Transport sector \\ (multi agent based model) \\ EU European Union \\ EU27 the 27 countries of the EU in 2010 \\ EU ETS European Emissions Trading System \\ EV electric vehicles \\ GMP German Mobility Panel \\ ILUTE integrated land use, transportation, environment \\ JI Joint Implementations \\ MAS multi agent (based) simulation \\ MATSim Multi Agent Transport Simulation \\ $\mathrm{N}_{2} \mathrm{O}$ nitrous oxide \\ NREAP National Renewable Energy Action Plans \\ PFC perfluorocarbon \\ PERSEUS EU Program Package for Emission Reduction \\ Strategies in Energy Use and Supply in Europe \\ (energy system model) \\ RES renewable energy sources \\ VMT vehicle miles travelled
}

cars. Unfortunately, this instrument focuses on the efficiency of the vehicles and therefore neglects the rebound effect. This means that more efficient cars lead to lower operating costs and therefore stimulate a higher mileage [7]. Even though the German transport sector is one of the few worldwide with decreasing $\mathrm{CO}_{2}$ emissions, most experts agree that technical measures of conventional pas senger cars alone will not enable vehicle manufacturers to meet the European reduction target $[8,9]$. This is mainly determined by the high technical $\mathrm{CO}_{2}$ emission abatement costs. On the other hand, these high costs could also be interpreted as a great willingness to pay for luxury passenger cars.

A first step towards including the transport sector in the EU ETS was taken in 2012, with all flights arriving at and/or departing from EU airports being included (European Directive 2008/101). The idea of integrating road transport in cap and trade and other approaches has been discussed extensively for several years (e.g. Refs. [10,11]). Due to the low price elasticity for fuel in road transport (e.g. Refs. $[12,13])$ and comparatively low marginal $\mathrm{CO}_{2}$ abatement costs in the energy sector, such an integration into the EU ETS leads to monetary flows from the transport sector to the other EU ETS sectors rather than to real emission reductions within the road transport sector. An efficient reduction of overall emission is, however, assured [14].

Today, significant emissions reductions within the European transport sector without the EU ETS seem to be unlikely. The his toric $\mathrm{CO}_{2}$ emissions development in the European transport sector shows that a reduction is impossible without a substantial change in the traffic participant's attitude, a technical breakthrough or a faster increase of transport cost in comparison to income gains. On the one hand, inclusion in the EU ETS would lead to a marginal increase in transport costs in road transport (which might be higher if stronger emission targets are imposed) and on the other hand it leads to an increased allowance demand in the EU ETS market, where the energy industries have a major market share. Hence, the main impacts of such an implementation could be a change in the price of allowances in the EU ETS and due to this in electricity generation as well as in mileage performance and vehicle fleet composition. Therefore, these impacts will be analysed in considering feedback to road transport itself and the mitigation potentials from energy industries. The interactions between these two sectors actually increase through the market penetration of EV (electric vehicles) - which seems to be relevant for the coming decades $[15,16]$. Hence, a model based approach is chosen for this analysis to cope with the high system complexity in a systematic way. This model approach has to adequately cover both sectors.

In the energy industry, mainly investment and production planning are affected by the EU ETS. Optimising energy system models enables an adequate analysis of the long term energy sys tem developments to be made for investment planning for power plants [17-26]. In the EU ETS, the development of the $\mathrm{CO}_{2}$ allow ance price depends mainly on the marginal $\mathrm{CO}_{2}$ abatement costs of European power plants and the $\mathrm{CO}_{2}$ reduction target. We therefore use an optimising energy system model (PERSEUS EU (Package for Emission Reduction Strategies in Energy Use and Supply in Europe $)^{1}$ ), which includes emissions trading and assumes opti mising agents in the energy industry [27,28]. The road transport sector, by contrast, is characterised by individual purchase de cisions (especially in passenger transport) of multiple actors with heterogeneous preferences and decision patterns. Here we apply the COMIT $\left(\mathrm{CO}_{2} \text { emission Mitigation in the Transport sector }\right)^{2}$ model, which is a MAS (multi agent based simulation) model, which is widely accepted as being able to cope with these (some times irrational) inhomogeneities [14]. As already stated, this combination of sophisticated models of both sectors is necessary in order to achieve sound results for our research question.

So far the two models have only been used separately and therefore contain only a reduced representation of the other sector. The corresponding results have thus never considered all the necessary aspects of the impact of road transport being included in the EU ETS. In the following, the results are harmonised and allow for the first time a consistent interpretation, insofar as both models use the same relevant parameter values (e.g. oil prices) and exchange their values for the demand and price of $\mathrm{CO}_{2}$ emission allowances.

The paper is structured as follows: After an outline of the two models applied, COMIT and PERSEUS EU, their data exchange and underlying scenarios are described. Subsequently, the model results are presented and their sectoral impacts are discussed. The paper concludes with a discussion of the impacts of an extended EU ETS on the German road transport and (European) electricity sectors.

\section{Modelling the German road transport sector by the COMIT model}

Multi agent simulation is a fairly new modelling approach in transport economics. The first MAS models focused more on network based approaches (e.g. MATSim (Multi Agent Transport Simulation) [29] and ILUTE (integrated land use, transportation, environment) [30]). As $\mathrm{CO}_{2}$ emission reductions of optimised routing and navigation seem lower than reductions from car fleet technology and mileage, we neglect the underlying road network for the following analysis [14]. The COMIT model used here focuses on mode shift, mileage reduction, and vehicle purchase decision for private households and freight forwarders.

\subsection{Model structure}

The COMIT model includes 700 different households and more than 600 different road freight transport actors, which represent

\footnotetext{
${ }^{1}$ Program Package for Emission Reduction Strategies in Energy Use and Supply in EUrope.

${ }^{2} \mathbf{C O}_{2}$ emission Mitigation in the Transport sector.
} 


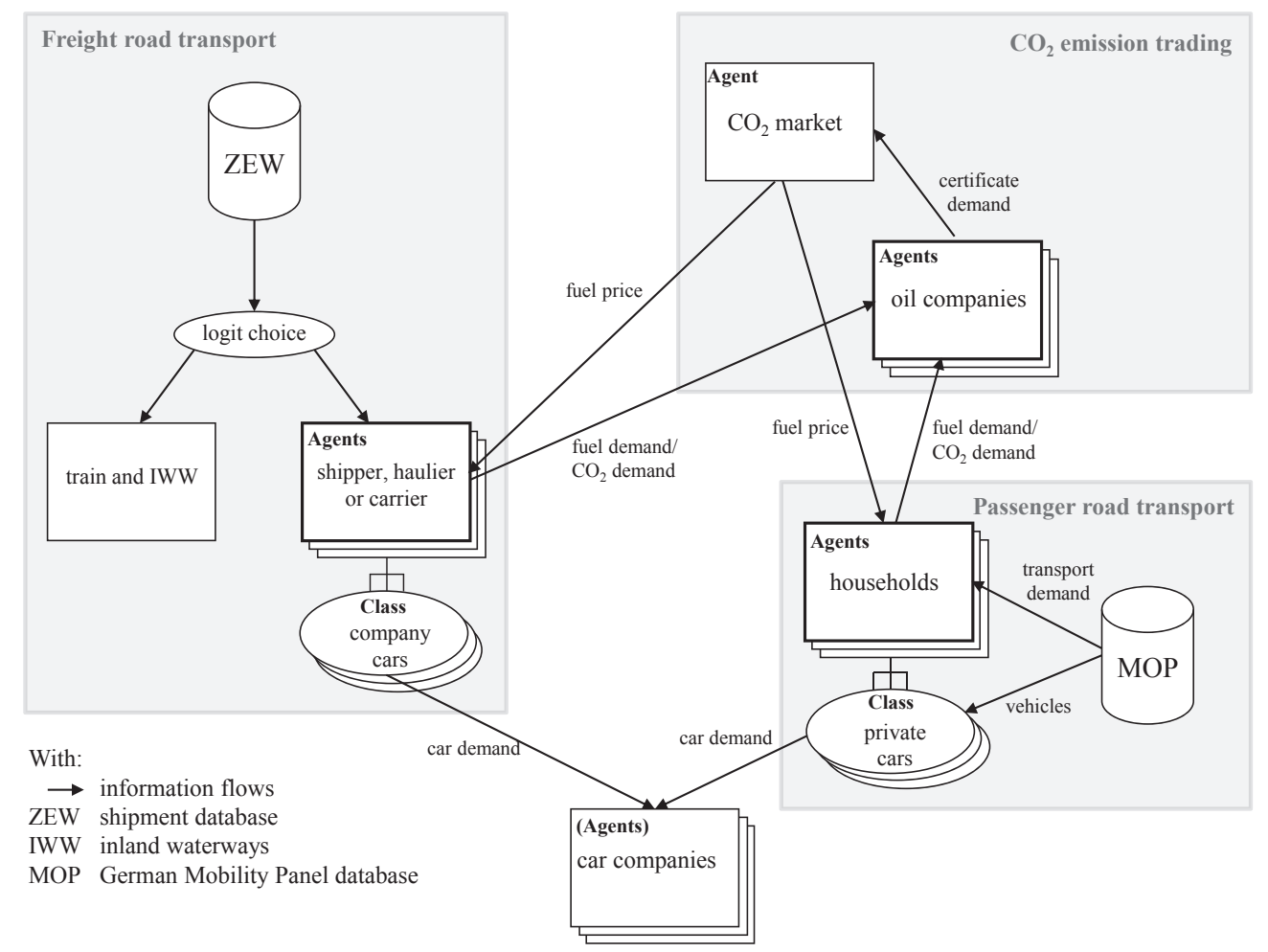

Fig. 1. Class diagram of the meso-economic model [14].

the German traffic participants. The model was developed to analyse the impact of an extension of the EU ETS to German road transport [14]. In the model, the main agents are private house holds (demanding fuel and new passenger cars), freight forwarders (demanding diesel and new freight vehicles), vehicle manufac turers (providing new cars), and oil companies (importing/refining and selling fuel) (Fig. 1). The latter actors are affected by the EU ETS and, hence, trade the allowances. Modelling of households and freight forwarders is based on empirical data [31,32]. A $\mathrm{CO}_{2}$ reduction path (number of allowances allocated to the oil com panies) is adapted to the German policy targets of $25 \%$ between 2010 and 2030 (derived from the objective for 2050 by Ref. [33]). The $\mathrm{CO}_{2}$ emission reduction in transport implies a continuous reduction of allowances during the simulation period for the obliged party (i.e. oil companies). As it is an open emissions trading system, this reduction of allowances does not necessarily imply a real reduction of $\mathrm{CO}_{2}$ emissions within the transport sector. If traffic participants ask for more fuel, the oil companies are forced to buy allowances on the residual EU ETS market. Hence, the reduction of emissions takes place in other sectors - but with a resulting in crease in the corresponding $\mathrm{CO}_{2}$ allowance prices, which will be marked up to the fuel price of the following day.

The core of the model consists of a loop, which represents an average exchange market day and which is repeated 264 times a year (Fig. 1). On each day represented, the traffic participants may adjust their VMT (vehicle miles travelled) according to current fuel prices (eq. (1)). Furthermore, the household agents decide once a year whether to buy a new (or used) car or continue to drive their old one. Simultaneously, freight forwarders randomly receive transport orders from the database [14] every day and execute these orders using trucks or combined means of transport (trucktrain-truck) according to the underlying logit model [31] (eq. (5)). If the fuel price increases, freight forwarders can avoid additional costs by using combined means of transport instead of trucks. Oil companies decide every evening whether to buy or to sell allowances on the EU ETS market or not to trade allowances at all, based on their shortage of allowances. ${ }^{3}$ The additional demand for allowances is transferred to the PERSEUS EU model and the resulting price for $\mathrm{CO}_{2}$ allowances is incorporated into the fuel price for the next day.

The reaction functions of households are generally difficult to estimate because individuals react differently to political in struments and the many influencing factors can hardly be measured [34-38]. Moreover, there has been no significant (real) fuel price increase in the last few decades in Germany (except in the late 70 s and 80s), ${ }^{4}$ which could be used to calibrate the model. A widely applied approach is to cluster some reaction functions ac cording to different types of households, regions or attitudes or to take social networks into consideration. The COMIT model sim plifies these influences and uses statistically estimated individual reaction functions based on empirical panel data [14].

\subsection{Main agents}

The 700 private households in the model, representing the 40 million German households, are defined by the following attri butes: monthly VMT (mileage ${ }_{n, i, k}$ ), fuel efficiency (fuelCombus $\operatorname{tion}_{n, i, k}$ ), car age ( $\left.\operatorname{carAge}_{n, i, k}\right)$, fuel type (diesel or not) (diesel ${ }_{i, k}$ ) of their vehicles, luxury car or not ( premium $_{i, k}$ ), paid fuel prices (fuelPrice ${ }_{i, t}$ ), household size (hhSize ${ }_{i}$ ), number of household members with a high school diploma $\left(n \mathrm{HSD}_{i}\right)$, number of employed household members $\left(n \mathrm{EP}_{i}\right)$, children under 10 years old living in the household $\left(\operatorname{kidD}_{i}\right)$, and holiday trip (holiday $\left.i\right)$ during the survey.

\footnotetext{
${ }^{3}$ In the model, their strategy is simplified to a daily balance of their allowance account.

${ }^{4}$ Whereas in the 70 s and 80 s the nominal fuel price change was about $20 \%$ p.a. on three occasions, there was no price change above the $10 \%$ corridor except in 2000 and 2010 within the last 15 years [38].
} 
Model inputs are transport panel data from a mobility survey, GMP (German Mobility Panel) [39], which include characteristics of more than 20,000 German traffic participants. To determine the reaction function of households to fuel price changes (eq. (1)), the COMIT model is based on a fixed effects panel regression model by Ref. [40]. The results are based on 1409 observations and are taken from [14:126ff].

$\ln \left(\right.$ mileage $\left._{n . i . k}\right) \quad 7.66+0.539 \cdot \ln \left(\right.$ fuelCombustion $\left._{n, i, k} / 100\right)$ $0.545 \cdot \ln$ (fuelPrice $\left._{i, t}\right) \quad 0.02 \cdot\left(\right.$ carAge $\left._{n, i, k}\right)$

$+0.21 \cdot$ diesel $_{i, k}+0.24 \cdot \operatorname{premium}_{i, k}+0.07 \cdot n \mathrm{HSD}_{i} \cdot 0.10 \cdot n \mathrm{EP}_{i}$

$+0.27 \cdot$ holiday $_{i}+0.11 \cdot \mathrm{kidD}_{i} \quad 0.0001 \cdot \ln \left(\mathrm{CO}_{2} \text { Price }_{i, t}\right)^{2}$

Here, $\ln \left(\right.$ mileage $\left._{n, i, k}\right)$ is the $\log$ of the monthly VMT of house holds $i \in\{1-I\}$ with car $k \in\{1-K\}$ in the year $n \in\{1-20\}$. It is influ enced positively by the fuel efficiency of the car, the diesel and the premium variable, the proxy of the education level of the house hold, the number of employed people in the household, as well as by the holiday and children variable. Negative influences are the fuel price, the car age, and the additionally included $\mathrm{CO}_{2}$ price variable (by adding the squared $\log$ ). This price reaction of house holds is determined every day $t \in\{1-264\}$ to adapt their VMT to the current fuel prices (which include the $\mathrm{CO}_{2}$ prices).

As depicted above, the second possibility of reacting to higher fuel prices is to buy a new car. The decision is based on a two stage approach (cf. [40] or [41]) and considers different car segments and drive chain technologies such as gasoline, diesel, compressed nat ural gas, liquefied petroleum gas and EV. In stage I, the household assesses once a year whether to buy a new (or used) vehicle. The underlying decision is based on a logistic function for each car $\left(U_{n, i, k}\right)$ composed of econometrically estimated parameters (eqs. (2) and (3)). For the model estimation $U_{n, i, k}$ equals one, if the empirical household bought a new car, if not $U_{n, i, k}$ is defined as zero. Dependent variables are the vehicle age of the current vehicle $\left(\right.$ carAge $\left._{n, i, k}\right)$, its annual mileage and the household type (hhtype $)^{5}{ }^{5}$ Within the COMIT model, the logistic error term is transformed into a uniformly distributed error term $\left(\varepsilon_{n, i, k}\right)$ between 0.1 and +0.1 .

$$
\begin{array}{ll}
U_{n, i, k} & 2.476+0.368 \cdot \ln \left(\text { carAge }_{n, i, k}\right) \\
+ & 0.263 \cdot \ln \left(\text { mileage }_{n, i, k}\right) \quad \text { hhtypeConst }_{i}+\varepsilon_{n, i, k}
\end{array}
$$

With hhtypeConst ${ }_{i} \quad\left\{\begin{array}{ccc}0.476, & \text { if } \text { hhtype }_{i} & 1 \\ 0.702, & \text { if } \text { hhtype }_{i} & 2 \\ 0, & \text { else } & \end{array}\right.$

From this estimated utility $U_{n, i, k}$ per vehicle, the probability of buying a car can be expressed by eq. (3).

$$
P_{n, i, k} \quad \frac{e^{U_{n, i, k}}}{1+e^{U_{n, i, k}}}
$$

If the probability of buying a vehicle $P_{n, i, k}$ is below a household specific uniformly distributed threshold between 0 and 1 , the household rejects the decision to buy a car, it continues to drive its old vehicle and the household is excluded from the car purchase decision module in the current year of simulation. Otherwise, it decides to buy a car and within the next step of stage I, the car age of the new vehicle is defined by an econometrically estimated

\footnotetext{
5 The German Mobility Panel distinguishes between four households types: (1) 12 person households with employed person(s), (2) 12 person households without employed persons (in particular pensioners), (3) households with children under the age of 18 , and (4) households without children and more than two adults (in particular shared accommodation).
}

function by Ref. [14]. This depends on the age of the current vehicle and the household type.

In stage II of the decision, the car segment is chosen according to the previous vehicle segment with a certain transition probability to the neighbouring segments (cf. [42]). Within this car segment, a representative vehicle for each drive chain technology (gasoline, diesel, gas, BEV (battery electric vehicle), and PHEV (plug in hybrid electric vehicle)) is taken from the COMIT vehicle database. In a next step, some alternatives are rejected due to the individual percep tion of the number of fuelling infrastructures, vehicle range or in dividual innovation friendliness [43].

The resulting reduced sample of cars within the segment is then transferred into stage III, where a utility value $\left(U_{n, i, k}\right)$ is calculated for each vehicle. The underlying utility function (eq. (4)) contains a techno economic weighted TCO (total cost of ownership) approach and a socio economic technology choice function based on a stated preference analysis by Ref. [44]. Both components are empirically acknowledged for the car purchase decision. Their weighting, however, is vague and person specific (cf. [45]). Nevertheless, many studies highlight the significance of the TCO approach $[40,41,46]$. Therefore, we choose a constant weighting of the two components with $\alpha \quad 0.7$ and $\beta \quad 0.3$ for the following calculations. This meets the current market situation satisfactorily.

In order to have comparable scales for both utility components, both are correspondingly transferred into the probability for choosing the considered vehicle. For the TCO component, the LUCE model [47] is used for the transformation, assuming the IIA condition for the vehicle sample. The LUCE model allows the use of a household specific weighting factor $\gamma_{i}$, indicating the involvement of the decision maker. In the current scenario it is set to 3 , which fits well with current market observations. For the second component of the utility function, the logit specific transformation (odds ratio) is used.

$U_{n, i, k} \quad \propto \cdot \frac{\left(U_{n, i, k}^{\mathrm{TCO}}\right)^{\gamma_{i}}}{\sum_{k \in K}\left(U_{n, i, k}^{\mathrm{TCO}}\right)^{\gamma_{i}}}+\beta \cdot \frac{e^{U_{n, i, k}^{\mathrm{SOC}}}}{\sum_{k \in K} e^{U_{n, i, k}^{\mathrm{SOC}}}}$

Finally, the household calculates the utility $U_{n, i, k}$ for each considered vehicle and chooses the vehicle with the highest utility. Then, the vehicle fleet in the COMIT model is updated corre spondingly. A detailed description is given in Ref. [43]. The COMIT model considers rebound effects of these technologies.

Within the COMIT model, agents in road freight transport (shippers, freight forwarders, and carriers) choose their mode of combined transport (i.e. truck-rail-truck) according to a statisti cally estimated nested logit model for German road transport by Ref. [31]. All orders of the shipping database from 500 (out of 3000) telephone interviews with German forwarders [31] are given with more than 30 variables. Most of them [26] are integrated in the logit model (eq. (5)). Therefore, the mode decision of forwarders de pends among other things on the number of employees of the forwarder, transport volumes on the considered relation, available time for scheduling, number of similar transports, duration of transport in combined transport and truck alone, costs of the two alternatives, etc.). The cost of transport depends on the fuel (and electricity) prices and is therefore the decisive variable here. All variables depend on the day $t$, forwarder $q \in\{1-600\}$ and shipment $o \in\{1-O\}$. Shipments with a mileage below $50 \mathrm{~km}$ are directly performed by truck alone.

CTTruck $_{t, q, o} \quad\left\{\begin{array}{cl}\beta \cdot X_{t, q, o}, & \text { for truckKm }>50 \mathrm{~km} \\ 1, & \text { for truckKm } \leq 50 \mathrm{~km}\end{array}\right.$

The freight forwarder's fleet is simplified in the model and is represented by a pool of identical trucks, of which the efficiency is 


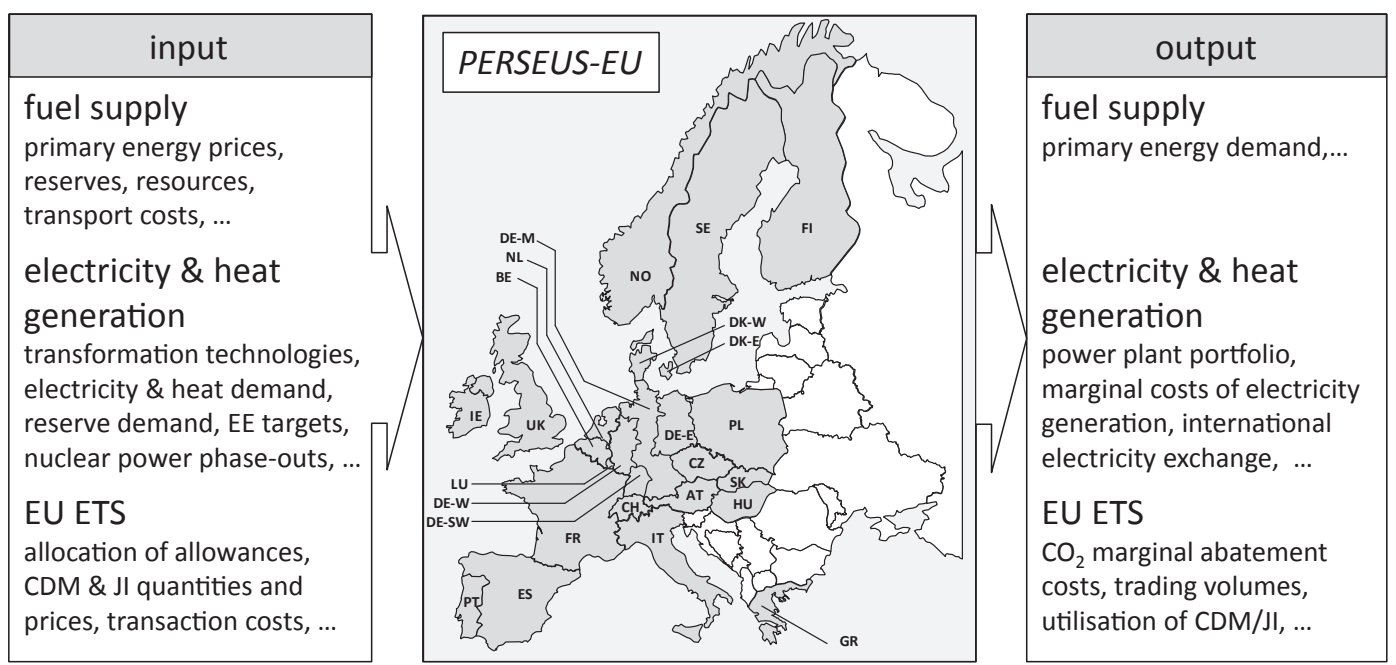

Fig. 2. Regional scope and main inputs/outputs of PERSEUS-EU.

upgraded by $0.2 \mathrm{~L}$ per $100 \mathrm{~km}$ every year (gain in efficiency less than 1\%). 600 freight road forwarders are implemented in the COMIT model, which represents the German freight road sector. In the COMIT model, it is assumed that the freight volumes increase by $1.6 \%$ per year [48] independently of the fuel costs.

\section{3. $\mathrm{CO}_{2}$ emission trading in the COMIT model}

As depicted above, the up stream emission trading system in the COMIT model affects the oil companies which have to have the right amount of allowances at the end of each trading period. This is achieved when the allocated allowances $\left(\mathrm{CO}_{2} \mathrm{Supply}\right)$ plus the additionally bought allowances (cerDemand) correspond to the amount of $\mathrm{CO}_{2}$ emissions produced by the fuel sold in this trading period $\left(\mathrm{CO}_{2}\right.$ Demand), which is defined as follows (eq. (6)). interdependency, an integrated approach regarding the develop ment of the European power plant portfolio as well as the corre sponding $\mathrm{CO}_{2}$ allowance price is needed.

To adequately consider $\mathrm{CO}_{2}$ emissions trading in an optimising energy system it is necessary to take the model costs and re strictions associated with the EU ETS into account. These include costs and restrictions of the $\mathrm{CO}_{2}$ abatement technologies as well as those associated with allowance and credit trading itself, and prices and quantities of JI (Joint Implementations) and CDM (Clean Development Mechanisms) credits. Additionally, the regional scope has to cover the main participating countries of the EU ETS as well as their cross national electricity exchanges.

The optimising energy system model PERSEUS EU is part of a model family widely used for different analyses of long term de velopments in the European energy system (see e.g. Refs.

$\mathrm{CO}_{2}$ Demand $_{t} \quad \sum_{i}^{I} \sum_{k}^{K}$ mileage $_{t, n, i, k} \cdot \frac{\text { fuelCombustion }}{t, n, i, k} \cdot \mathrm{CO}_{2}$ Factor $_{j}+\sum_{q}^{600}$ mileage $_{t, q} \cdot \frac{\text { fuelCombustion }_{t, n, q}}{100} \cdot \mathrm{CO}_{2}$ Factor $_{\text {diesel }}$

Therefore the daily $\mathrm{CO}_{2}$ demand of road transport participants $\left(\mathrm{CO}_{2}\right.$ Demand $\left.{ }_{t}\right)$ depends on the individual mileage of households or trucks (mileage $e_{t, n, i, k}$ and mileage $e_{t, q}$ ), fuel efficiency per kilometre (fuelCombustion $_{t, n, i, k}$ and fuelCombustion ${ }_{t, n, q}$ ) and the corre sponding emission factor of fuel $\left(\mathrm{CO}_{2}\right.$ Factor $\left._{j, \text { diesel }}\right)$, where $j$ indicates the fuel types (diesel, gasoline or premium gasoline). The sum of the daily $\mathrm{CO}_{2}$ demand of one year has to equal the amount of al lowances held by the oil company. $\mathrm{CO}_{2}$ demand from the traffic participants minus the allowances allocated to the oil companies equals the additional allowance demand on the existing EU ETS modelled in PERSEUS EU.

\section{Modelling the German electricity sector by the PERSEUS-EU model}

The development of the $\mathrm{CO}_{2}$ allowance price in the EU ETS de pends mainly on the $\mathrm{CO}_{2}$ reduction target and the marginal $\mathrm{CO}_{2}$ abatement costs of the European power plants, which represent the predominant EU ETS sector. In turn, the electricity sector is signif icantly influenced by the $\mathrm{CO}_{2}$ allowance price. Due to this
$[28,49,50])$. It is based on an inter regional electricity balance throughout Europe and encompasses the electricity systems of 22 countries (Fig. 2) on a technologically highly detailed level, with nearly 3000 unit classes, each of which has even more processes. ${ }^{6}$ While the EU ETS covers even more countries, for the scope of this paper it is sufficient to consider only those countries that emit the major part of the $\mathrm{CO}_{2}$ emissions covered by the EU ETS.

The construction and operation of power plants are subject to several (technology specific) techno economic restrictions in the model. These include among others the availability of installed power plant capacities, ramp rates, minimum or maximum full load hours, and (de)commissioning constraints. These restrictions allow an adequate description of the existing and future energy system in Europe, including power plant operation and future capacity development (for more details see Ref. [28]). The driver for the expansion and operation of power plants in the model is the exogenously given demand for electricity. Its time

\footnotetext{
${ }^{6}$ Such models are also called bottom-up models.
} 


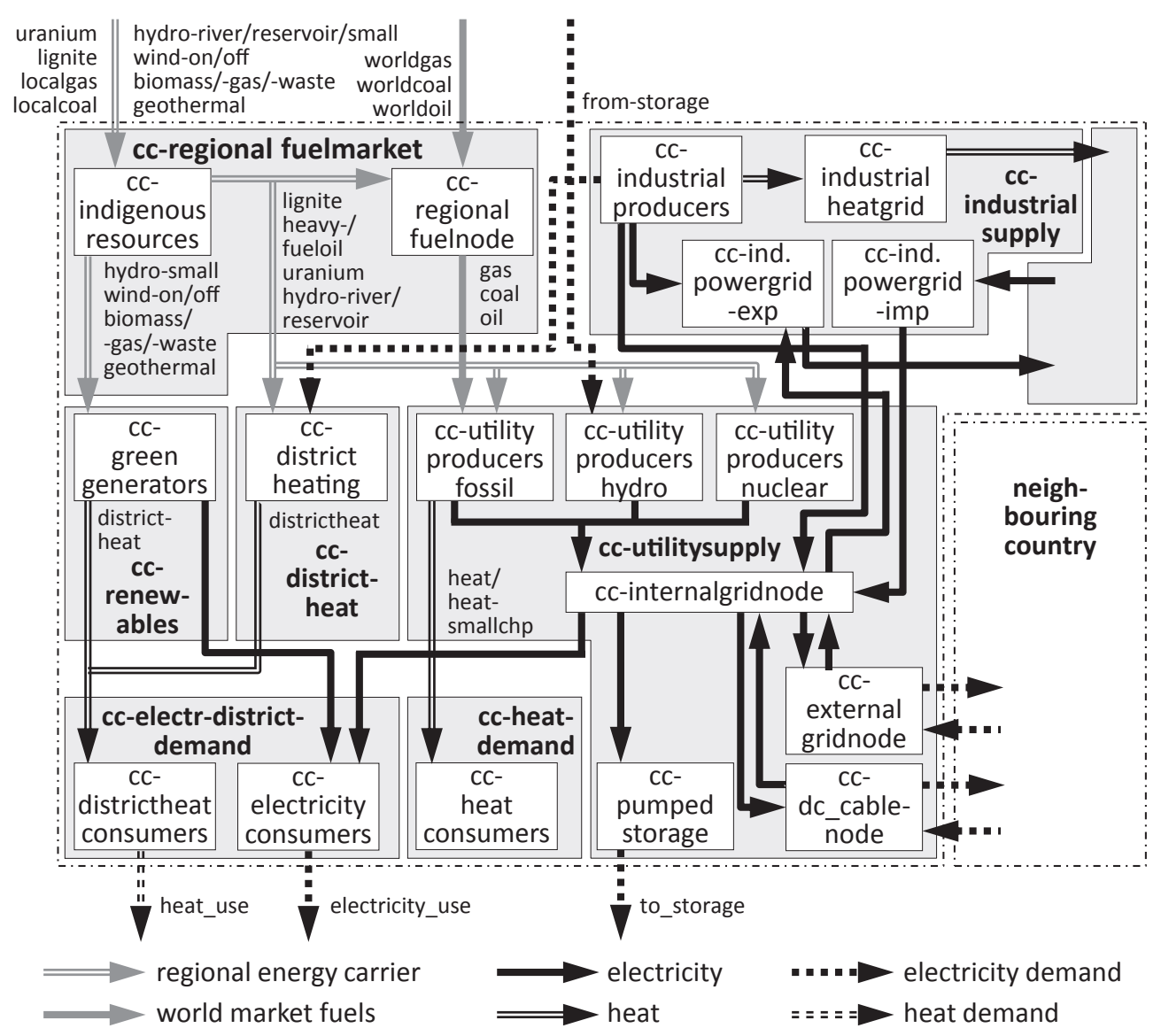

Fig. 3. Model structure of PERSEUS-EU [28].

differentiated demand profile of one year is represented by 44 time slices, which are structured in four seasons with 2 type days [18]. The complete time horizon covered in this analysis extends up to 2030 .

The model structure is presented to give an overview of the system boundaries and coverage. Additionally the objective func tion of PERSEUS EU is introduced, constituting the decision crite rion of the model. After this short overview of PERSEUS EU, the modelling of the EU ETS is explained in more detail.

\subsection{Model structure}

In the PERSEUS EU model, each cc (country considered) is modelled separately and shows the same model structure (Fig. 3). This structure consists of several sectors which can be grouped into fuel supply, electricity, and heat generation as well as final energy demand for electricity and heat. While the model focuses on the electricity sector, also heat generation, transport, and de mand have to be taken into account in order to consider the in terdependencies between the two energy forms (i.e. in combined heat and power generation). The fuel supply sector includes indigenous resources and supplies from outside the country. This sector provides the input energy carriers for the energy conversion sector, which contains the public and industrial electricity and heat production. Additionally, energy conversion based on RES (renewable energy sources) and the generation of district heat are treated separately in this sector in order to consider their specific characteristics (i.e. district heat pipeline transport). The electricity is fed into a transmission grid node, while heat is provided either directly to the final heat consumers or to the end user via onsite industrial heat grids. The electricity transmission grid node transports electricity to the final energy demand sector as well as to the pumped storage power plants. Furthermore, this node is connected to the interconnections between the European coun tries (overhead power transmission lines and underground direct current transmission lines).

\subsection{Objective function}

The linear objective function of PERSEUS EU (eq. (7)) is based on a minimisation of all decision relevant system expenditures discounted to the base year of 2007 ( $\alpha$ : discount factor). It in cludes all expenditures related to energy flows $\left(\mathrm{FL}_{\mathrm{ec}, t}\right)$, to power plant operation ( $\mathrm{PL}_{\mathrm{proc}, t}$ ) and power plant capacities (Capunit,t and NewCapunit, $t$ ) as well as to the EU ETS. For the energy flows of each ec (energy carrier), in each period $(t)$ between two pro ducers (prod and prod' $^{\prime}$ or imp, exp) fuel costs (Cfuel $\mathrm{ec}_{\mathrm{e}, t}$ ), trans mission fees $\left(\mathrm{Cfee}_{\mathrm{ec}, t}\right)$, and other expenditures $\left(\mathrm{Cvar}_{\mathrm{ec}, t}\right)$ (i.e. financial incentives for renewable energies) are taken into ac count. Considering variable costs $\left(\mathrm{Cvar}_{\mathrm{proc}, t}\right)$, fixed operational costs $\left(\mathrm{Cfix}_{\mathrm{unit}, t}\right)$, investments $\left(\mathrm{Cinv}_{\mathrm{unit}, t}\right)$, and load change costs $\left(\right.$ Cload $\left._{\text {unit, } t}\right)$ allows us to consider the operation and capacity development of new and existing power plants and their load

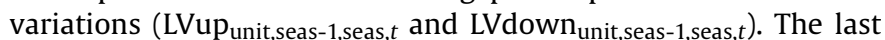
two elements of the objective function include costs related to the EU ETS, such as transaction costs $\left(\mathrm{Ctrans}_{\mathrm{CO}_{2}, t}\right)$ and penalties for violating emission caps $\left(\mathrm{Cpen}_{\mathrm{CO}_{2}, t}\right)$ as well as expenditures for credits from $\mathrm{CDM}$ and $\mathrm{JI}$ projects $\left(\mathrm{Ckyo}_{\mathrm{kyoID}, t}\right)$. Hence, the 
modelling approach covers three optimisation problems, namely, system expansion planning, capacity production planning, and $\mathrm{CO}_{2}$ emission trading. and the emission allowances (EmissRights ${ }_{\mathrm{sec}, \mathrm{CO}_{2}, t}$ ). The emissions trading balance (eq. (9)) is complemented by two supplementary elements: additional emissions which are subject to a mostly

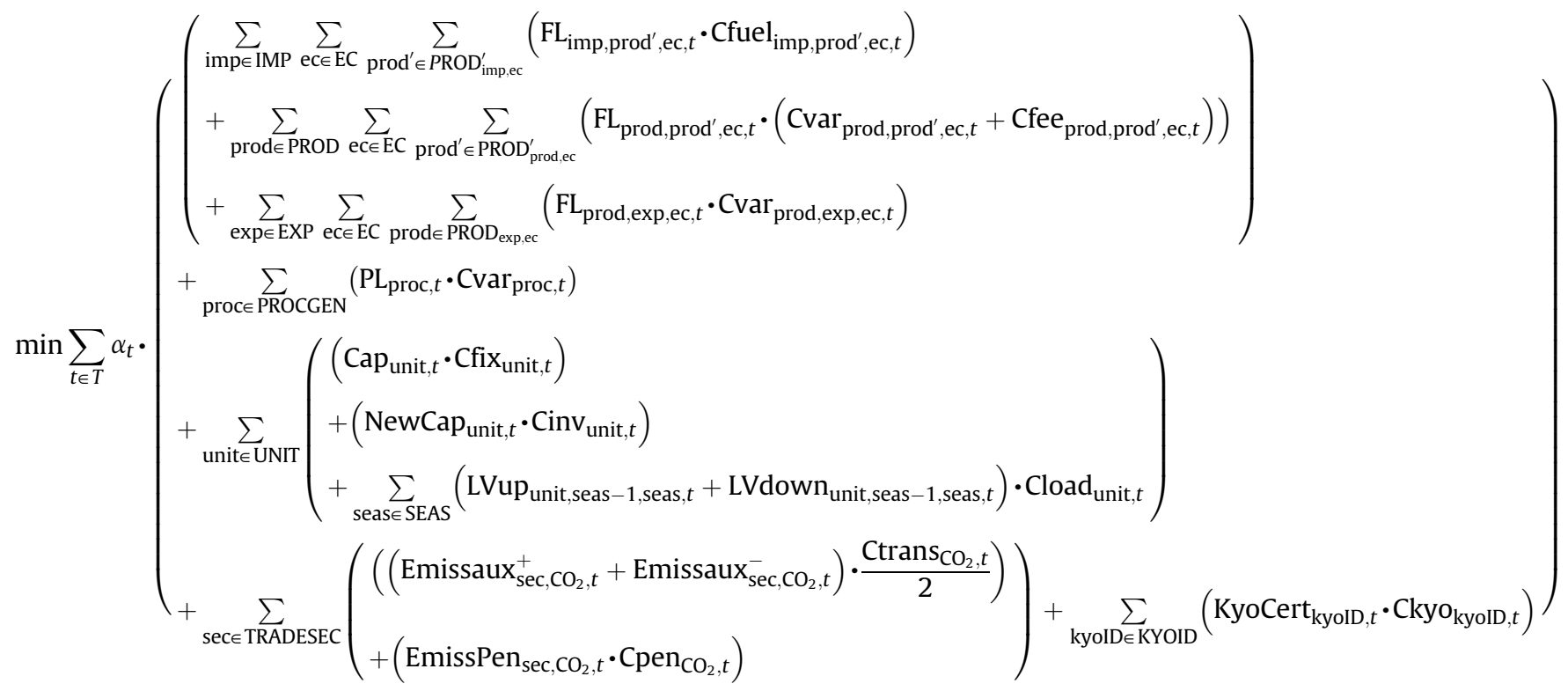

\section{3. $\mathrm{CO}_{2}$ emissions trading}

In the PERSEUS EU model, a quantity based approach is used to integrate the EU ETS. The formerly free commodity $\mathrm{CO}_{2}$ is now linked to emission allowances. In reality, the obliged agents are individual companies, but in order to reach a compromise between model size and level of detail, sectors are used as market agents. These market agents are connected via transmission lines and the emissions trading system. Hence, electricity production is allocated within the framework of transmission line capacities and the EU ETS trading restrictions in the model until the decision relevant system expenditures are minimised.

This quantity based approach in PERSEUS EU covers the following equations. First, the $\mathrm{CO}_{2}$ emission volume $\left(\right.$ EmissVol ${\mathrm{sec}, \mathrm{CO}_{2}, t}_{\text {) }}$ of each sector $(\mathrm{sec})$ in period $(t)$ is calculated as the product of the utility level of each process $\left(\mathrm{PL}_{\mathrm{proc}, t}\right)$ in the affected sectors and the specific $\mathrm{CO}_{2}$ emission factors (EmissProc $\mathrm{CO}_{2}$,proc, $t$ ) (eq. (8)). To take emissions in the supply chain into account, emissions of the energy flows (EmissFlow $\mathrm{CO}_{2, \text { prod,prod', ec, }, \text { }}$ ) can be included in the model.

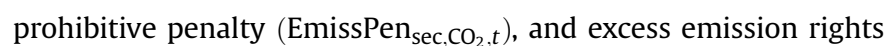
which are not tradable due to exogenously given restrictions

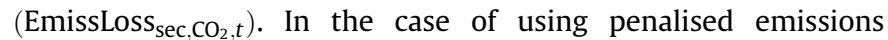
$\left(\right.$ EmissPen $\left._{\mathrm{sec}, \mathrm{CO}_{2}, t}\right)$, the emission rights of the next period (EmissRights ${\mathrm{Sec}, \mathrm{CO}_{2}, t+1}$ ) will be reduced by the amount of these penalised emissions from the previous period.

$$
\begin{aligned}
\Delta \text { Emiss }_{\mathrm{sec}, \mathrm{CO}_{2}, t} & \text { EmissVol }_{\mathrm{sec}, \mathrm{CO}_{2}, t} \quad \text { EmissRights } \\
& + \text { Emiss }_{\mathrm{sec}, \mathrm{CO}_{2}, t} \\
&
\end{aligned}
$$

\section{$\forall t \in T ; \forall$ sec $\in$ TRADESEC}

Third, at the end of each trading period the amount of $\mathrm{CO}_{2}$ emissions in the EU ETS sectors has to equal the sum of emission allowances and permitted Kyoto credits from JI or CDM projects. The available amount and the corresponding costs of these credits are modelled as cost potential steps [28]. The banking option and further optional trading restrictions are also implemented. Addi tionally, costs incurred by the trading of allowances and credits (Ctrans $\left.\mathrm{CO}_{2}, t\right)$ are considered in the objective function.

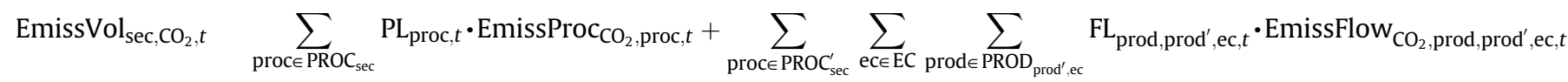

\section{$\forall t \in T ; \forall \sec \in \mathrm{SEC}$}

Second, the sectoral $\mathrm{CO}_{2}$ emissions trading volume results from the difference between the $\mathrm{CO}_{2}$ emission volume (EmissVol ${\mathrm{sec}, \mathrm{CO}_{2}, t}_{\text {) }}$
Due to the coupling of $\mathrm{CO}_{2}$ emissions trading with the capacity expansion planning of the European countries, this approach al lows us to analyse the interdependencies between and impacts on both sectors in an integrated and consistent way. 


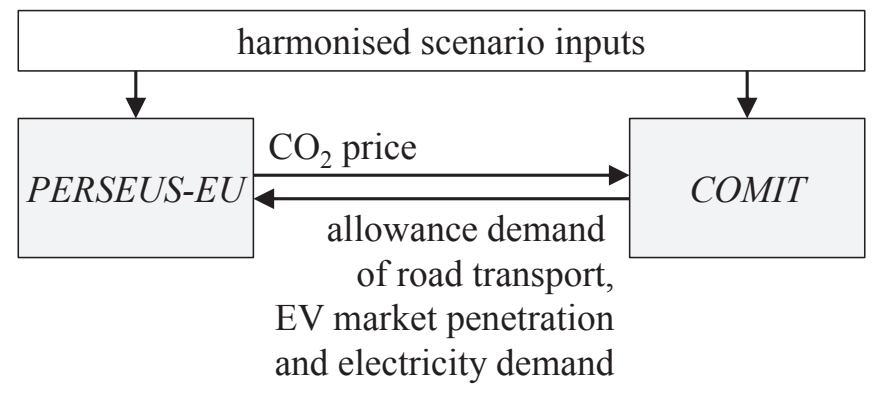

Fig. 4. Model coupling scheme.

\section{Model coupling, scenario definition, and critical appraisal}

In this section, we first explain the model coupling. Subse quently, we define the four main scenarios in our analysis. Further scenario variations are subsequently discussed. The section con cludes with a critical appraisal of the chosen models and the overall approach.

\subsection{Model coupling}

The coupling of the two models (Fig. 4) starts with a model run of PERSEUS EU, which provides the initial development of $\mathrm{CO}_{2}$ emission allowance prices as an input for the COMIT model. COMIT, in turn, uses this input information to calculate the need for $\mathrm{CO}_{2}$ emission allowances for the road transport sector. With this addi tional demand, the German overall $\mathrm{CO}_{2}$ emission cap in PERSEUS $E U$ is adjusted and a new model run is started. This model loop is continued until no further change of the $\mathrm{CO}_{2}$ emission cap is needed. Sufficient result convergence is usually reached after only two to five model runs.

In scenarios including electric mobility, additional parameters have to be exchanged between the models. Namely, COMIT calcu lates the German market penetration of EV. In order to account for the additional electricity demand by EV on the European level which seems necessary to account for the pan European EU ETS the German market penetration is then multiplied by the German market share within the European passenger car fleet. This factor will be around 7 until 2030 if the current European fleet develop ment is considered [51]. ${ }^{7}$ These data are transformed into a suitable format (load curve and electricity demand) and transferred to PERSEUS EU as exogenous parameters.

Ultimately, a balance between $\mathrm{CO}_{2}$ emission mitigation options in the electricity and road transport sectors is obtained, and the influence on $\mathrm{CO}_{2}$ allowance prices of an extension of the EU ETS to the German road transport sector can be analysed.

\subsection{Scenario definition}

In addition to the exchange of parameter values, our analysis comprises two main scenario paths. These scenarios are based on the CP (Current Policy) and NP (New Policy) scenarios from the World Energy Outlook [52] (Table 1). They represent two com modity price development paths to analyse the impact of different fuel prices. In the Current Policy scenario, the crude oil price in creases from US\$ 63 per barrel in 2010 to US\$ 125 per barrel in

\footnotetext{
7 Due to the great uncertainty of this market share, we also considered the factors 5 and 10 as sensitivities. Our results, however, confirm only a very marginal impact on the installed capacity $(<1 \%)$ and $\mathrm{CO}_{2}$ emissions $(<€ 1$ per tonne in 2030$)$.
}

2030. In the New Policy scenario, the price rises to US\$ 106 per barrel.

In order to estimate the impact of $\mathrm{EV}$ on these scenarios, both scenarios are calculated with and without the option of buying EV. The parameter set 'electric mobility' was chosen as an additional scenario variation, because the electricity and road transport sec tors interact strongly, especially regarding $\mathrm{CO}_{2}$ mitigation strate gies. This results in a total of four main scenarios. In order to show the impact of a very high market penetration of $\mathrm{EV}$, we also calculated a scenario (High EV), where all the parameters within the purchase decision for EV are changed to unrealistically positive values. This includes complete availability of charging stations at home and at the workplace, a change of doubts about EV to a preference for $\mathrm{EV}$, a stronger weight of vehicle operating costs, a rapidly decreasing battery price, and we assume a permanently available second car for all households (e.g. car sharing).

In addition, the scenarios contain different goals for electricity from renewable energy sources (RES) after 2020. The RES targets of the two scenarios Current Policy (with and without EV) are extrapolated to 2030 with half of the average increase of the period from 2010 to 2020. In the other two scenarios, the RES targets from 2021 onward are assumed to have the same average increase of the prior period. As the goals for renewable energies are calculated as a percentage of gross final electricity demand as outlined in the NREAP (National Renewable Energy Action Plans) of each European country [53], the absolute amount of renewable electricity pro duced is higher in scenarios with EV due to the overall higher electricity demand (s. Table 2). In order to analyse the impact of even higher RES targets on the enlargement of the EU ETS, we additionally examine scenarios up to twice the RES amount in 2030 compared to the New Policy scenarios. However, these results show only a minor impact on our analysis focus. Therefore we do not discuss them in more detail in the results section.

Concerning the EU ETS cap, all scenarios are based on the NAPs and assume a Europe wide cap decrease of $1.74 \%$ per year up to

Table 1

Main scenario assumptions.

\begin{tabular}{|c|c|c|}
\hline Scenario & Parameter & Assumed development \\
\hline \multirow[t]{2}{*}{ Current Policy } & Crude oil price & $\begin{array}{l}\text { Increase to } 125 \mathrm{US} \$ / \mathrm{bbl} \text { in } 2030 \\
\text { (equals gasoline priced from } € 1.45 \\
\text { to } € 1.98 \text { up to } 2030 \text { for Germany) }\end{array}$ \\
\hline & RES targets & $\begin{array}{l}\text { Up to } 2020 \text { according to the NREAPs; } \\
\text { since } 2021 \text { half of average yearly } \\
\text { increase of } 20102020\end{array}$ \\
\hline \multirow[t]{2}{*}{ New Policy } & Crude oil price & $\begin{array}{l}\text { Increase to } 106 \mathrm{US} \$ / \mathrm{bbl} \text { in } 2030 \\
\text { (equals gasoline priced from } € 1.45 \\
\text { to } € 1.82 \text { up to } 2030 \text { for Germany) }\end{array}$ \\
\hline & RES targets & $\begin{array}{l}\text { Up to } 2020 \text { according to the NREAPs; } \\
\text { since } 2021 \text { average yearly increase } \\
\text { of } 20102020\end{array}$ \\
\hline
\end{tabular}


Table 2

Assumed total electricity demand of Germany ([18,54] and own calculations).

\begin{tabular}{llll}
\hline Electricity demand [TWh] & 2010 & 2020 & 2030 \\
\hline Without EV & 522.5 & 507 & 495 \\
With 6\% EV & 522.5 & 510 & 507 \\
With 50\% EV & 522.5 & 517.5 & 537 \\
\hline
\end{tabular}

2013. In the transport sector, a (so far non binding) reduction target for the $\mathrm{CO}_{2}$ emissions of road transport by the German Federal Government is $10 \%$ (40\%) by 2020 (2050) compared to the 2005 emission levels [32]. Based on these targets, we assume a reduction target of $25 \%$ in 2030 compared to 2010 for all scenarios in the COMIT model. This equals an average $\mathrm{CO}_{2}$ emission reduction of about $1.1 \%$ per annum for road transport.

\subsection{Critical appraisal}

With respect to the modelled road transport market, it has to be pointed out that the car purchase decision by households is a rather complex process. There are numerous models for representing this decision and the results are diverse [55]. For this reason and due to its minor impact on our analysis here, it is strongly simplified in the COMIT model [14]. Furthermore, the assumption of equal market shares of EV in all European countries states only a rough estimation.

It has to be emphasised that PERSEUS EU focuses on the long term development of the European power plant portfolio only. For such an analysis, scope optimising energy system models are widely used as documented in the model description. However, this means that no statements regarding developments in the short term (i.e. daily change of $\mathrm{CO}_{2}$ prices) are possible. Additionally, volatile feed in of renewable energies has to be considered in a simplified manner using side constraints for power and energy reserve requirements as well as for operation of peak load power plants (i.e. gas turbines). These limitations of the applied model only influence the results of this paper to a small extent, because the long term effects dominate the analysis findings.

As both models are coupled via a soft link, the convergence of the results cannot be guaranteed. Furthermore, the electricity price is not exchanged iteratively between the two models as it does not have a significant influence on the total costs of ownership during the EV lifetime [56] - especially for the small price changes of our analysis. Hence, marginal changes in the electricity price do not directly affect the EV market penetration.

\section{Model results of the transport sector}

Due to a considerable increase in trade volumes within the EU [57], which cannot be compensated by the technical efficiency gains of the truck fleet, a slightly increasing amount of $\mathrm{CO}_{2}$ emis sions of road freight transport can be observed. This leads to a convergence of the $\mathrm{CO}_{2}$ emission shares of households and carriers in the COMIT model - even though passenger transport still con tributes more than two thirds in 2030. Hence, the emission reduction of $1.1 \%$ p.a. is more precisely an emission reduction of about $2 \%$ p.a. for passenger road transport and a slight increase of $\mathrm{CO}_{2}$ emissions by freight road transport. This is due to the fact that the reduction efforts of car manufacturers will increase consider ably due to EU Regulation 443/2009, which targets a specific limit of $\mathrm{CO}_{2}$ emissions per km and light duty vehicle of $120 \mathrm{~g}$ in 2015 and $95 \mathrm{~g}$ in 2020 for the average light duty vehicle fleet sold. For the new vehicle fleet, this means a significant increase in the historic emission reduction path of $1.1 \%$ p.a. to about 3\% p.a. up to 2015 and to about $6 \%$ p.a. up to 2020 . This development, together with an electrification of the drive train, leads to decreasing operating costs and therefore to a rebound effect and increasing mileage. An appropriately designed ETS can better cope with this rebound ef fect, at least for $\mathrm{CO}_{2}$ emissions, as it focuses on total emissions. The rebound effect might however lead to increasing air pollutants and other negative effects which are neglected here. The COMIT model results show that traffic participants in Germany do not respond to the shortage in allowances and increased fuel prices in all scenarios, but continue to drive a relatively stable mileage corresponding to the level of recent years. This is not surprising as an allowance price of about 50 euros per ton of $\mathrm{CO}_{2}$ only leads to a fuel price increase of $7 \%$ in 20 years (i.e. 10 cents per litre) (Fig. 5). The corresponding fuel prices based on the crude oil price of the corresponding scenario and the allowance price of the EU ETS increase by less than $2 \%$ p.a. on average, which is comparable to the historical German fuel price

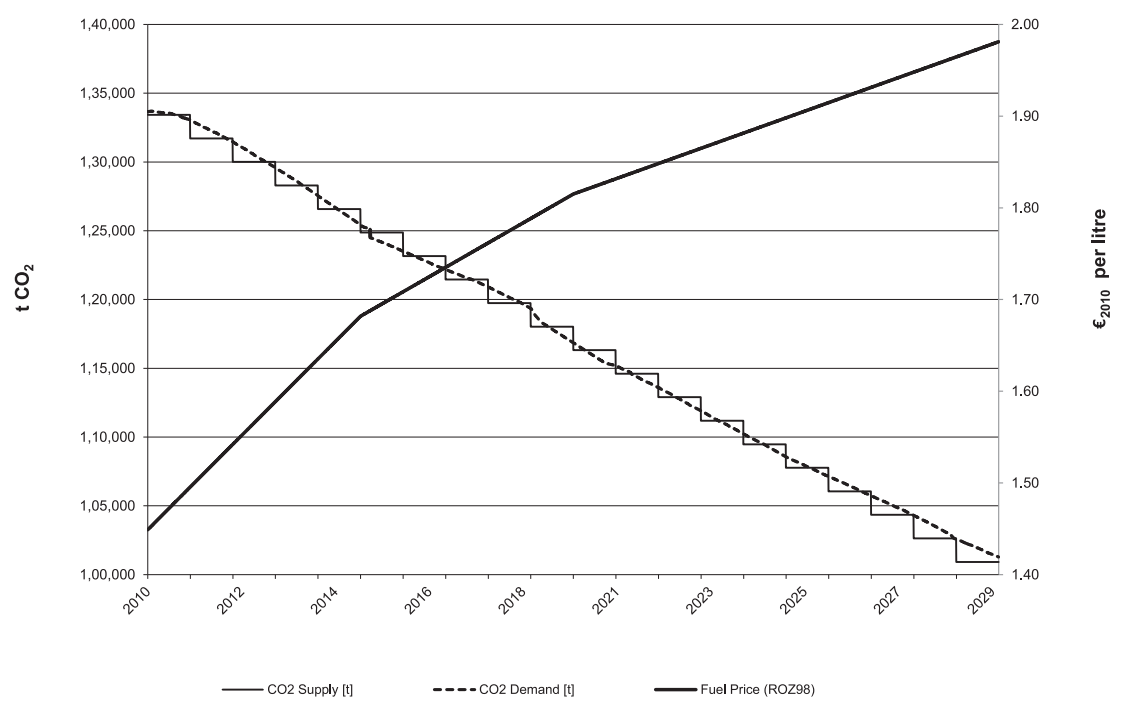

Fig. 5. Simulation results for $\mathrm{CO}_{2}$ supply and demand as well as real fuel prices in German road transport for the $\mathrm{CP}$ scenario with $6 \%$ market share of EV. 

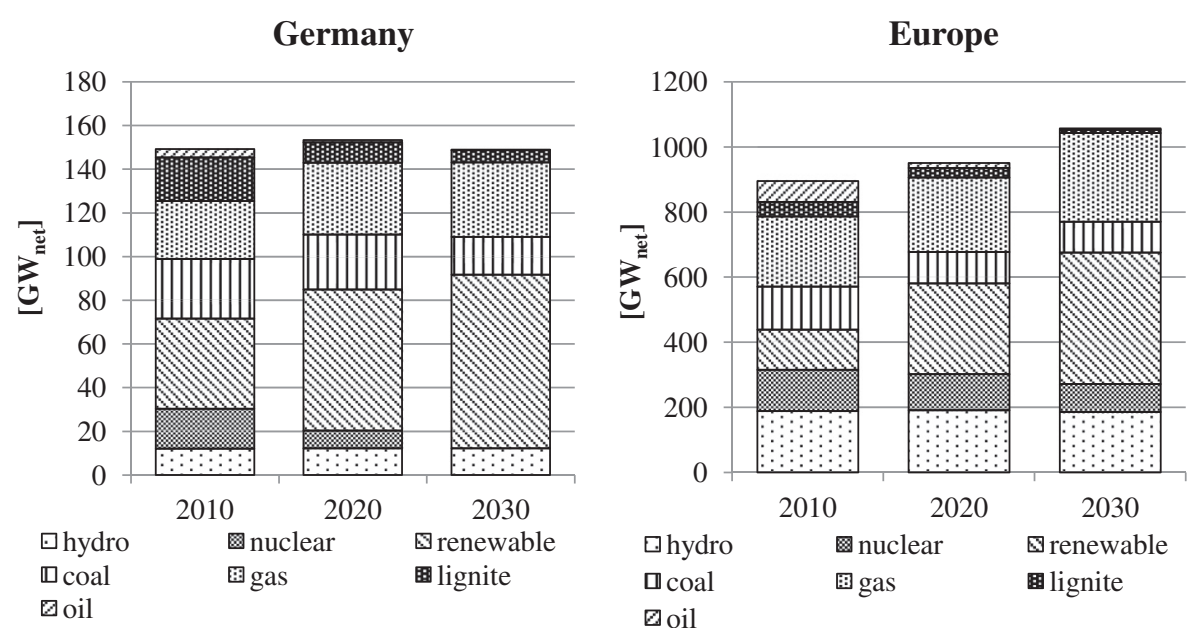

Fig. 6. Development of power plant net capacity (Current Policy without EV scenario).

development [58]. Thus, the impact on the households' decisions on transport is small. Hence, we might argue that the emissions trading system will only make the transport sector pay for its emissions and not really contribute to emission reductions in road transport. Nevertheless, the impact on car dependent households (especially in the countryside) could be significant in terms of their additional expenditures. An increasing fuel price of $10 \%$ equals an additional expenditure of about 15 euros per month. In forcing the road transport sector to decrease its emissions, the costs for society seem to be higher. The ETS guarantees the efficient achievement of the overall $\mathrm{CO}_{2}$ reduction target, but does not (necessarily) decrease $\mathrm{CO}_{2}$ emissions in the transport sector.

The impact on freight transport is equally low. Fierce competi tion on the European freight transport market, however, may react sensitively to these price changes. Especially long distance ship ments are affected. A redistribution of revenues or a lowering of other fuel taxes might, however, lower the additional burdens of the road transport actors.

With respect to the shares of EV, only minor effects were identified for the scenarios with different EV shares. The estimated market share of EV in 2030 amounts to $10-11 \%$ - with about $70 \%$ BEV. The penetration rate is only $0.6 \%$ higher in the Current Policy scenario than in the New Policy scenario. Only for the High EV scenario is there a market share of $44 \%$ due to very optimistic EV assumptions (Section 4.2) In order to measure the impact on the European scale, we included similar EV market penetration rates based on [18] for all other Member States. Apparently, this low market penetration leads to minimal reduction of $\mathrm{CO}_{2}$ emissions within road transport by less than $6 \%$ for the Current Policy and New Policy scenario but to about $20 \%$ within the High EV scenario.

The results confirm that the enlargement of the EU ETS leads to an economically efficient mitigation of $\mathrm{CO}_{2}$ emissions in the econ omy, as the marginal abatement costs are significantly lower than the technical measures, which correspond to certificate prices of far more than $€ 100$ per tonne of $\mathrm{CO}_{2}[59,60]$. With respect to $\mathrm{CO}_{2}$ mitigation in passenger road transport alone, EU regulation 443/ 2009 seems to be more effective.

\section{Model results of the electricity sector}

In all scenarios considered, the exogenously stipulated expan sion of RES is accompanied by a significant increase of gas power plant capacities in Europe and Germany up to 2030 of between 19 and 37\% compared to 2010 (Fig. 6). In contrast to gas fired power plants, the share of lignite use decreases considerably (Germany $13.4 \%$ to $5.7^{8}-3.4 \%$, EU $5 \%$ to approx. $1 \%$ ) as does the Europe wide share of nuclear power plants ( $14.2 \%$ to $8-4.3 \%$ ). Oil fired power plants play a diminishing role up to 2030 . However, the develop ment of coal fired power plants varies between the scenarios. In the Current Policy scenarios, coal use initially declines, but increases slightly in later periods with increasing EV shares. In the New Policy scenarios, the corresponding increase of coal use does not appear. One reason is the exogenously given higher amount of renewable energies in the New Policy compared to the Current Policy scenarios. Due to the higher share of volatile RES supply, a further increase in flexible power plants, e.g. gas turbines, is required. In turn, the full load hours of coal fired power plants are reduced significantly. Additionally, renewable energies expand more strongly in sce narios with electric mobility, because EV increase final electricity consumption. Thus, since the percentage of RES in gross final electricity demand is fixed, the total amount of RES grows. Depending on the EV share and therefore on the total electricity demand, the overall power plant capacity in Europe grows between 18 and 34\% from 2010 to 2030, while the growth in Germany is rather small and ranges up to $8 \%$. This small growth is caused by currently existing overcapacities. The biggest growth occurs in those scenarios which possess high RES shares and high EV shares. The reasons therefore are the comparatively small full load hours of RES and the additional final electricity demand of EV compared to the other scenarios.

Besides these basic developments, several impacts on the elec tricity sector due to the enlargement of the EU ETS can be identi fied. In scenarios with an additional allowances demand due to the enlargement of the EU ETS, more nuclear and gas power plants are utilised compared to scenarios without EU ETS enlargement. In contrast, in scenarios with an additional allowances supply and electricity demand due to $\mathrm{EV}$, mainly the share of coal and in part of lignite power plants increases. Independently of a demand or supply of allowances from COMIT, different RES shares do not change the impact on the electricity sector, which occur, if the EU

\footnotetext{
${ }^{8}$ Only in the High EV scenarios is this slightly higher share of lignite power plants found. With higher RES shares this effect vanishes.

${ }^{9}$ Only in scenarios with the highest RES shares does the share of nuclear power plants reach this lower value.
} 


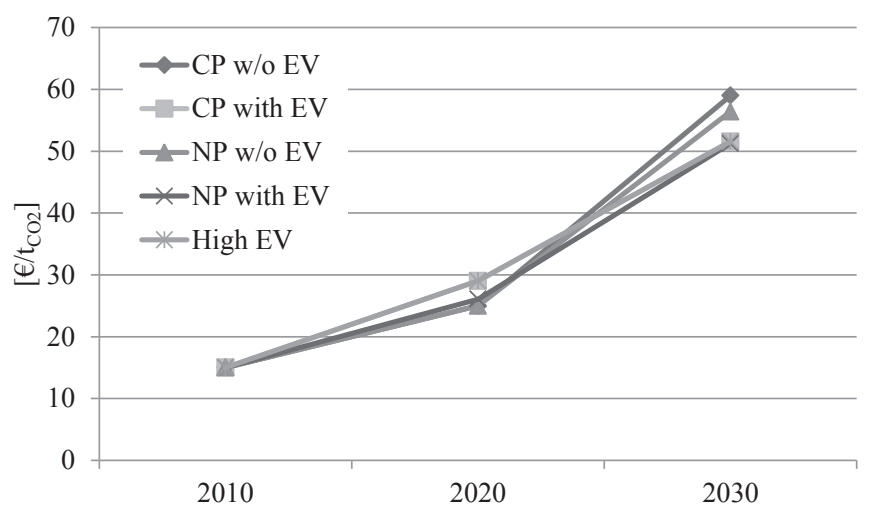

Fig. 7. Development of marginal $\mathrm{CO}_{2}$ abatement costs.

ETS is extended to the road transport sector. Therefore we do not discuss different RES shares in more detail.

Different EV ratios show only marginal impacts on the German power plant fleet, because the carbon reduction in the transport sector caused by the replacement of ICEV (internal combustion engine vehicle) by EV approximately equals the additional $\mathrm{CO}_{2}$ emissions in the energy sector caused by the specific emissions of electricity for EV. On the European scale, this effect is less ambig uous. A higher share of EV leads for our enlarged EU ETS system to a higher availability of certificates and therefore to a slight increase of fossil fuels in the energy sector. Nonetheless, extending the EU ETS to road transport affects the electricity sector much less than RES targets or existing $\mathrm{CO}_{2}$ reduction targets. This also holds true for electricity generation in Germany and Europe.

The marginal $\mathrm{CO}_{2}$ abatement costs nearly quadruple up to 2030, but only diverge after 2020 (Fig. 7). This strong rise results mainly from continued $\mathrm{CO}_{2}$ cap reduction, which leads to the necessity of using more and more expensive mitigation options. The extension of the EU ETS to the road transport sector influences the develop ment of the marginal $\mathrm{CO}_{2}$ abatement costs at maximum from

$8 € / \mathrm{t}_{\mathrm{CO}_{2}}$ (COMIT supply: Current Policy with $50 \%$ ) to $+5.5 € / \mathrm{t}_{\mathrm{CO}_{2}}$ (COMIT demand: New Policy w/o EV) in 2030. The differences in $\mathrm{CO}_{2}$ abatement costs due to the additional $\mathrm{CO}_{2}$ demand from COMIT and due to the additional electricity demand of $\mathrm{EV}$ are in the same order of magnitude.

The differences in $\mathrm{CO}_{2}$ emissions of the German electricity sector in the scenarios depend on diverse aspects, particularly on the investment decision in PERSEUS EU, which is based on a perfect foresight approach and the additional demand or supply of $\mathrm{CO}_{2}$ allowances from COMIT. Therefore, and due to the fact, that only small differences in $\mathrm{CO}_{2}$ emissions occur with an EU ETS enlarge ment, a general conclusion is hardly possible and mainly depends on COMIT results regarding the EU ETS enlargement.

\section{Conclusions and outlook}

If the anthropogenic impact on climate change by greenhouse gases and the alarming rate of global warming is accepted, a comprehensive reduction of greenhouse gases, i.e. in particular $\mathrm{CO}_{2}$, is essential. In the European context, all sectors contribute to emission reductions except for the transport sector. This is ineffi cient from an economic point of view (cf. [61]). On the global scale, the predicted strongly increasing passenger vehicle fleet and freight transport volumes are precursors of a considerable increase in future $\mathrm{CO}_{2}$ emissions up to 2050. This development requires strong political commitments on the global level.

A political instrument discussed for reducing $\mathrm{CO}_{2}$ emissions in the transport sector is including road transport in the EU ETS by an upstream scheme. Oil companies would have to trade allowances for the carbon content of their fuel sold. This concept would lead to a decreasing amount of overall $\mathrm{CO}_{2}$ emissions, but will not guar antee that the sector specific reduction targets are reached. Since the marginal abatement costs differ in the sectors, the EU ETS leads to an efficient abatement of emissions.

An analysis of the impact of this emissions trading concept has to consider the road transport and the energy sector in parallel. Therefore, we applied two models: a model for road transport, COMIT [14], and the electricity system model PERSEUS EU. Furthermore, both models are extended by considering EV in order to analyse these additional effects on the EU ETS and the electricity sector.

The result of the simulation is that traffic participants do not react significantly to increased allowance prices. This is not sur prising, as a price increase of allowance prices of $€ 10$ leads to an increase in fuel prices of only $€ 0.02$ (about $1 \%$ ). Only the techno logical improvements of vehicles lead to a slightly decreasing amount of $\mathrm{CO}_{2}$ emissions within road transport. This effect is, however, somewhat reduced by the rebound effect. Due to the decreasing number of allowances in the road transport sector, this leads to an increased allowance demand by oil companies in the EU ETS. However, this is not sufficient to raise the overall market price for $\mathrm{CO}_{2}$ allowances in the EU ETS significantly from the transport sector's point of view, because the share is too small and the electricity sector has further emission reduction potentials at comparably low marginal abatement costs. Hence, the price impact on the EU ETS through an integration of road transport is limited. Even if the costs are passed on to the final consumer (vehicle user), the development of $\mathrm{CO}_{2}$ emissions in road transport remains almost unaffected. This leads to an economically efficient situation where the transport sector (the vehicle user) pays for emission reductions in the electricity sector. Hence, the only possibility of reducing $\mathrm{CO}_{2}$ emissions in passenger transport seems to be a change in user behaviour, e.g. an accelerated trend towards more fuel efficient cars (e.g. EV). As shown by our model results, the impact of the assumed shares of EV on the power plant portfolio and EU ETS market is rather marginal. On the European level, a higher share of $\mathrm{EV}$ decreases the pressure to reduce $\mathrm{CO}_{2}$ emissions somewhat compared to a situation without EV. Therefore, the re sults recommend including road transport into a future phase of the EU ETS in order to reduce national $\mathrm{CO}_{2}$ emissions.

All COMIT model results presented are limited to Germany, and the results of PERSEUS EU are limited to the EU. With respect to the global scale, a stronger increase in vehicle fleet and freight trans port volumes should be considered - especially in emerging mar kets. Furthermore, the development of the national power plant portfolio and the charging strategy of EV have an effect on the re sults (cf. [62-64]). The general trend of the results, however, re mains the same.

\section{References}

[1] EU (European Union). Fact sheet the EU Emissions Trading System (EU ETS) http://ec.europa.eu/clima/publications/docs/factsheet_ets_2013_en.pdf; 2013 [accessed Aug. 2013]

[2] EC (European Commission). EU energy in figures $2010 \quad \mathrm{CO}_{2}$ emissions by sector http://ec.europa.eu/energy/observatory/statistics/doc/2010_ext_co2_ emissions_by_sector_2010.pdf; 2012 [accessed May 2013].

[3] EU (European Union). EU transport in figures 2012 [accessed May 2013], http://ec.europa.eu/transport/facts-fundings/statistics/doc/2012/ pocketbook2012.pdf; 2012.

[4] WBCSD (World Business Council for Sustainable Development). Mobility 2030. Geneva, Switzerland; 2004.

[5] BMU (Federal Ministry for the Environment, Nature Conservation, and Nuclear Safety). Langfristszenarien und Strategien für den Ausbau der erneuerbaren Energien in Deutschland bei Berücksichtigung der Entwicklung in Europa und global "Leitstudie 2010". Berlin, Germany; 2010. 
[6] Nagl S, Fürsch M, Paulus M, Richter J, Trüby J, Lindenberger D. Energy policy scenarios to reach challenging climate protection targets in the German electricity sector until 2050. Util Policy 2011;19:185 92.

[7] Frondel M, Peters J, Vance C. Identifying the rebound theoretical issues and empirical evidence from a German household panel. RWI Discussion Paper 57; Essen, Germany; 2007.

[8] Wallentowitz H, Freialdenhoven A, Olschewski I. Strategien zur Elektrifizierung des Antriebstranges: Technologien, Märkte und Implikationen. Wiesbaden, Germany; 2010.

[9] AEA (Association ASPEN), CE Delft, TNO, Öko-Institut. Assessment of options for the legislation of $\mathrm{CO}_{2}$ emissions from light commercial vehicles. Final report. Didcot, UK; 2009. http://ec.europa.eu/clima/events/0019/final_report_ lcv_co2_250209_en.pdf.

[10] Raux C. A system of tradable $\mathrm{CO}_{2}$ permits applied to fuel consumption by motorists. Transp Policy 2005;12:255 65.

[11] Flachsland C, Brunne S, Edenhofer O, Creutzig F. Climate policies for road transport revisited (II): closing the policy gap with cap-and-trade. Energy Policy 2011;39:2100 10.

[12] Goodwin P, Dargay J, Hanly M. Elasticities of road traffic and fuel consumption with respect to price and income: a review. Transp Rev 2004;24(3):275 92.

[13] Blom MJ, Kampman BE, Nelissen D. Price effects of incorporation of transportation into EU ETS. Project report. Delft, Netherlands; 2007. http://www. ce.nl/art/uploads/file/07_4553_37.pdf.

[14] Jochem P. A CO $\mathrm{CO}_{2}$ emission trading scheme for German road transport assessing the impacts using a meso economic model with multi-agent attributes. PhD thesis. Universität Karlsruhe $(\mathrm{TH})$. Baden-Baden, Germany: Nomos; 2009. http://www.nomos-elibrary.de/index.php?dokid 103860 http://dx.doi.org/10.5771/9783845219462.

[15] Kay D, Hill N, Newman D. Powering ahead the future of low-carbon cars and fuels http://www.theengineer.co.uk/Journals/2013/04/22/i/k/h/powering ahead-kay_et_al-apr2013-embargoed_copy.pdf; 2013 [accessed 30.11.13].

[16] Kiviluoma J, Meibom P. Methodology for modelling plug-in electric vehicles in the power system and cost estimates for a system with either smart or dumb electric vehicles. Energy 2011;36(3):1758 67. http://dx.doi.org/10.1016/j. energy.2010.12.053.

17] Cormio C, Dicorato M, Minoia A, Trovato $M$. A regional energy planning methodology including renewable energy sources and environmental constraints. Renew Sustain Energy Rev 2003;7(2):99 130.

[18] Gerbracht H, Möst D, Fichtner W. Impacts of plug-in electric vehicles on Germany's power plant portfolio a model based approach. In: Proceedings of the 7th conference in the European Energy Market (EEM2010); Madrid, Spain. http://ieeexplore.iee.org/stamp/stamp.jsp?arnumber 05558696; 2010 [accessed May 2013].

[19] Götz B, Voß A, Blesl M, Fahl U. Die Auswirkungen des EEG auf das Energiesystem Deutschlands Eine Betrachtung mit dem Energiesystemmodel TIMES-D. Z für Energiewirtschaft 2011:35(3):183 94.

[20] Kannan R. The development and application of a temporal MARKAL energy system model using flexible time slicing. Appl Energy 2011;88(6):2261 72 .

[21] Martinsen D, Funk C, Linssen J. Biomass for transportation fuels a cost effective option for the German energy supply? Energy Policy 2010;38:128 40 .

[22] Molt S. Entwicklung eines Instrumentes zur Lösung großer energiesystemanalytischer Optimierungsprobleme durch Dekomposition und verteilte Berechnung. Report. Stuttgart, Germany: IER-Forschungsbericht Band 84 Institut für Energiewirtschaft und Rationelle Energieanwendung; 2001. http:// d-nb.info/963292757.

[23] Nakata T, Silva D, Rodionov M. Application of energy system models for designing a low-carbon society. Prog Energy Combust Sci 2011;37(4):462 502.

[24] Remme U. Zukünftige Rolle erneuerbarer Energien in Deutschland: Sensitivitätsanalysen mit einem linearen Optimierungsmodell. PhD thesis. Germany: Universität Stuttgart; 2006.

[25] Strachan N, Balta-Ozkan N, Joffe D, McGreevor K, Hughes N. Soft-linking energy systems and GIS models to investigate spatial hydrogen infrastructure development in a low-carbon UK energy system. Int J Hydrogen Energy 2009;34(2):642 57.

[26] Keppo I, Strubegger M. Short term decisions for long term problems the effect of foresight on model based energy systems analysis. Energy 2010;35(5):2033 42

[27] Möst D, Genoese M, Eßer A, Rentz O. European electricity and emission market modeling the design of emission allocation plans and its effects on investment planning. In: IEEE Proceedings of the 5th Conference on the European electricity market (EEM); 2008

[28] Rosen J. The future role of renewable energy sources in European electricity supply: a model-based analysis for the EU-15. Germany: Universitätsverlag Karlsruhe; 2007.

[29] Hatzopoulou M, Hao JY, Miller EJ. Simulating the impacts of household travel on greenhouse gas emissions, urban air quality, and population exposure. Transportation 2011;38:871 87

[30] Salvini P, Miller EJ. ILUTE: an operational prototype of a comprehensive microsimulation model of urban systems. Networks Spatial Econ 2005;5(2): 21734.

[31] Bühler G. Verkehrsmittelwahl im Güterverkehr. Heidelberg, Germany; 2006.

[32] German Mobility Panel. Data from the German Mobility Panel http://www. mobilitaetspanel.de; 2011 [accessed May 2013].

[33] Bundesregierung (German Federal Government). Das Energiekonzept der Bundesregierung 2010 und die Energiewende 2011. Berlin, Germany; 2011.
[34] Götz K, Loose W, Schmied M, Schubert S. Mobilitätsstile in der Freizeit Minderung der Umweltbelastungen des Freizeit- und Tourismusverkehrs. Final report. Berlin, Germany; 2003. http://www.isoe.de/ftp/fzmob_zusfsg. pdf.

[35] Hunecke M, Tully CJ, Bäumer D. Mobilität von Jugendlichen Psychologische, soziologische und umweltbezogene Ergebnisse und Gestaltungsempfehlungen. Final report. Opladen, Germany; 2002. http://www.springer.com/ springer+vs/soziologie/familiensoziologie/book/978-3-8100-3672-8.

[36] Hunecke M, Schubert S, Zinn F. Mobilitätsbedürfnisse und Verkehrsmittelwahl im Nahverkehr. Int Verkehrswes 2005;57(1+2):26 33.

[37] Zinn F, Hunecke M, Schubert S. Zielgruppen und deren Mobilitätsbedürfnisse im Nahverkehr der Ballungsräume sowie im ländlichen Raum. Final report. Dortmund, Germany; 2003. http://www.forschungsinformationssystem.de/ servlet/is/95887/.

[38] Poganietz WR, Jochem P, Schäuble J, Grunwald A, Fichtner W. Prolog. In: Jochem P, Poganietz WR, Grunwald A, Fichtner W, editors. Alternative Antriebskonzepte bei sich wandelnden Mobilitätsstilen. Karlsruhe, Germany; 2012.

[39] Vortisch P, Zumkeller D, Chlond B, Kagerbauer M, Wirtz M, Streit T. Erhebungswellen zur Alltagsmobilität sowie zu Fahrleistungen und Treibstoffverbräuchen; 2011.

[40] Mueller M, de Haan P. How much do incentives affect car purchase? Agentbased microsimulation of consumer choice of new cars part I: model structure, simulation of bounded rationality, and model validation. Energy Policy 2009;37:1072 82 .

[41] Mock P, Hülsebusch D, Ungethüm J, Schmid SA. Electric vehicles a model based assessment of future market prospects and environmental impacts. In: EVS24 conference proceedings; Norway; 2009.

[42] Mueller M, De Haan P. Autokaufentscheid: Treue zur Marke, zum Fahrzeugsegment, zur Treibstoffart und zum Getriebetyp deskriptive Auswertung von Transaktionsdaten. Project report. Zürich, Switzerland: ETHZ; 2006. http://www.uns.ethz.ch/res/irl/emdm/ETH_CH-Autokauf_10_Transakt_ EMDM3221.pdf.

[43] Jochem P, Babrowski S, Kaltenbacher N, Fichtner W. Electric vehicle market penetration and corresponding $\mathrm{CO}_{2}$ emissions: a German case study for 2030 . In: Proceedings of IAEE-Conference, Düsseldorf, Germany; 2013.

[44] Achtnicht $\mathrm{M}$. German car buyers' willingness to pay to reduce $\mathrm{CO}_{2}$ emissions. Clim Change 2012;113(3):679 97

[45] Hjorthol R. Attitudes, ownership and use of electric vehicles a review of literature. Project report, Oslo, Norway; 2013. http://www.compett.org/ documents/wp_2_report_attetitudes_ownership_and_use_of_electric vehicles_a_review_of_literature.pdf.

[46] Brand C, Anable J, Tran M. Accelerating the transformation to a low carbon passenger transport system: the role of car purchase taxes, feebates, road taxes and scrappage incentives in the UK. Transp Res Part Policy Pract 2013;49:132 48

[47] Luce RD. The choice axiom after twenty years. J Math Psychol 1977;15(3): 21533.

[48] Progtrans. Abschätzung der langfristigen Entwicklung des Güterverkehrs in Deutschland bis 2050. Final report. Basel, Switzerland; 2007. http://www.dfld. de/Presse/PMitt/2008/080314a2.pdf.

[49] Eßer-Frey A. Analyzing the regional long-term development of the German power system using a nodal pricing approach. PhD thesis, Karlsruhe, Germany; 2012. http://digbib.ubka.uni-karlsruhe.de/volltexte/1000028367.

[50] Möst D, Fichtner W. Renewable energy sources in European energy supply and interactions with emission trading. Energy Policy 2010;38(6):2898 910 .

[51] Eurostat. Eurostat database www.ec.europa.eu/eurostat; 2013 [accessed Apr. 2013].

[52] IEA (International Energy Agengy). World energy outlook http://www. worldenergyoutlook.org/publications/weo-2010/; 2010 [accessed Dec. 2012].

[53] EC (European Commission). National Renewable Energy Action Plans http://ec. europa.eu/energy/renewables/action_plan_en.htm; 2012 [accessed June 2012].

[54] Capros P, Mantzos L, Tasios N, De Vita A, Kouvaritakis N. EU energy trends to 2030 update 2009. European Commission, Directorate-General for Energy; 2010.

[55] Mohammadian A, Miller EJ. Dynamic modelling of household automobile transactions. Transp Res Rec 2003;1831:98 105.

[56] Rousseau A, Badin F, Redelbach M, Kim N, Da Costa A, Santini D, et al. Comparison of energy consumption and costs of different HEVs and PHEVs in European and American context. In: European Electric Vehicle Conference (EEVC); 2012 Nov. 19 22; Brussels, Belgium; 2012.

[57] Progtrans. World transport reports 2010/2011. Basel, Switzerland; 2010.

[58] BMVBS (Federal Ministry of Transport, Building, and Urban Affairs). Verkehr in Zahlen. Berlin; 2011.

[59] ICCT (International Council on Clean Transportation). Reducing $\mathrm{CO}_{2}$ and fuel consumption: a summary of the technology potential for new cars in the $\mathrm{EU}$. Available from: http://www.theicct.org/sites/default/files/publications/ Briefing\%20Technology\%20Potential\%20Short\%20EN\%20v3.pdf; January 2013.

[60] IKA (Institut für Kraftfahrzeuge, Strategie und Beratung). $\mathrm{CO}_{2}$ Reduzierungspotenziale bei Pkw bis 2020 Abschlussbericht. RWTH Aachen University; 2012. Available from: http://www.bmwi.de/BMWi/Redaktion/PDF/ Publikationen/Studien/co2-reduzierungspotenziale-bei-pkw-bis-2020-abschlussbericht,property pdf,bereich bmwi2012,sprache de,rwb true.pdf.

[61] Bartocci A, Pisani M. "Green" fuel tax on private transportation services and subsidies to electric energy. A model-based assessment for the main European 
countries. Energy Econ 2013;40(1):S32 57. http://dx.doi.org/10.1016/j.eneco. 2013.09.019.

[62] Zhang Q McLellan BC, Tezuka T, Ishihara KN. A methodology for economic and environmental analysis of electric vehicles with different operational conditions. Energy 2013;61:118 27. http://dx.doi.org/10.1016/j.energy.2013. 01.025 .
[63] Hedegaard K, Ravn H, Juul N, Meibom P. Effects of electric vehicles on power systems in Northern Europe. Energy 2012;48(1):356 68. http://dx.doi.org/10. 1016/j.energy.2012.06.012.

[64] Metz M, Doetsch C. Electric vehicles as flexible loads a simulation approach using empirical mobility data. Energy 2012;48(1):369 74. http://dx.doi.org/ 10.1016/j.energy.2012.04.014. 
Karlsruher Institut für Technologie

\section{Repository KITopen}

Dies ist ein Postprint/begutachtetes Manuskript.

Empfohlene Zitierung:

Heinrichs, H.; Jochem, P.; Fichtner, W.

Including road transport in the EU ETS (European Emissions Trading System): A modelbased analysis of the German electricity and transport sector.

2014. Energy, 69.

doi: $10.5445 / / R / 1000077441$

Zitierung der Originalveröffentlichung:

Heinrichs, H.; Jochem, P.; Fichtner, W.

Including road transport in the EU ETS (European Emissions Trading System): A modelbased analysis of the German electricity and transport sector.

2014. Energy, 69, 708-720.

doi:10.1016/..energy.2014.03.061 